\title{
Accounting Practices among Business Firms and the Identification of the Unique Features
}

Hong-xia Liu

Nanyang Normal University

Nanyang City 473061, Henan Province

China

ABSTRACTS: In modern society, both enterprises and institutions would face a common problem which was how the accounting staff handle the finances. Due to the different properties, this two types of units could lead to the difference how to handle this units. This paper was to research and analyze problems from this aspect, and based on the analysis and research, and to compare the specific difference of institutions and enterprises, then put forward the corresponding point of view for research better understanding.

Keywords: Institutions, Enterprises, Accounting Staff, Financial Processes, Difference

Received: 5 May 2019, Revised 19 July 2019, Accepted 5 August 2019

DOI: $10.6025 / \mathrm{pms} / 2019 / 8 / 2 / 48-51$

(C) 2019 DLINE. All Rights Reserved

\section{Introduction}

The economic system is set to record changes and it has influence on society. The most obvious reflection was in the accounting field. Our country had implemented a new accounting standard for business enterprises, and made our country's accounting standards gradually bridge to the world. And we all knew that institution was the national department, which was the non-profit organization, the main purpose was to provide public service for the society. As the country further reforms had penetrated in a wide range of industries in society, there was no exception for institutions. The state had reformed the management mode of institutions, and made the management pattern of institution was similar to enterprises operation and management mode. In the end of 2012, the institution accounting system had been issued, this system had exceeded the previous accounting system, and also showed the characteristics of accounting management system reform after institution. Although the enterprises and public institutions were quite different in accounting management, the two organization had certain similarities between them. From the accounting system of the two organization, this study analyzed the two systems were different, this could assist institutions learn from enterprises management mode, and offer assistant to deepen the reform of institutions.

\section{Basic Classification of Accounting}

There was a process for the forming of accounting system in our country. The forming of this system was mainly to convenience 
people daily financial management. In general, according to the accounting object, it was divided into two categories: enterprise accounting and budget accounting. Enterprise accounting was mainly suitable for society organization, including agriculture, industry, business, enterprise unit. Its purpose was to supervise and manage each combination and process of social production in the field of enterprise capital operation situation. While, the budget accounting applied to the government department, institutions and administrative unit of the society. Its purpose was to supervise and manage the process of social production, material distribution and social welfare institutions in funds management field. Typically, government departments and institutions did not directly provide material products, instead, they mainly provided some public services for the society, played a significant role in social production activities. The main difference between the enterprises and institutions was social functions. When institutions held various public activities, most were paid by individuals or units, and the investment was free and voluntary. Most of the money was appropriation by national finance department. Therefore, the accounting management of institutions was based on the social benefits, such as measurement, recording, reporting, etc.

\section{Reason Analysis of Institutions and Enterprises for Accountant Processing}

In financial accounting treatment, institutions and enterprises had a very big difference, here listed was the reason why the difference exists and the analysis of the three aspects:

- The fundamental reason for the difference between institutions and enterprises was because the unit was a big difference in nature between. The differences of course was only part of the reason, and enterprises and institutions internal financial management aspects of the difference is more obvious. Institution was to provide public service for the society, it was a nonprofit organization, their work was unpaid, and basically no profit. Institution was mainly to ensure the normal development of society and people's daily activities. Enterprise unit was focused on the maximization of self-interest, so many of their daily activities and accounting work was based on profit for the purpose. In addition, the institution of the profit and loss had nothing to do with the unit itself, while the company unit of profit was closed related to its loss.

- Institutions and enterprises were the main reason for the difference, was because they both had significant difference on the internal capital form. Under the normal circumstances, the institution of the funds was very fixed, his internal capital form is divided into two kinds: liquidity and conserve cash. Institution's liquidity referred to the government's funding, these funds in the process of circulation was basically not possible money back. Regular money was fixed assets within the unit. And enterprises and institutions were quite different in this respect, in addition to some fixed building enterprise unit, the rest of the money had been in circulation in order to be able to earn more money, the differences made them in financial accounting treatment be a very big difference.

- For institutions and enterprises, there were a difference in terms of money, this was what they both in financial accounting treatment of different direct cause. Capital operation was to do something with money. To some extent, the institution of capital operation was a form of social services and establishing a good security system for the society. So, enterprises in the use of funds, was considering how to legalize the funds. The enterprise units were more to take the money out to invest other business and expect in return for greater economic benefits, realized the enterprise capital flow, they were considered when using money more and how to make these funds into maximize interests.

\section{Financial Accounting Treatment Differences of Institutions and Enterprises}

\subsection{The Difference in the form of Accounting Entries}

In daily work, the basic work of accounting staff was resorting the accounting work. The capital of the work on the establishment of the financial records had a vital role, the difference of capital entry work was enterprises and institutions in the financial accounting treatment of a concrete embodiment. For institutions and enterprises to take loans, we illustrated it would be different results even the loan subject was same, due to the two units was different in area of financial system. Therefore, accounting staff would sort the accounts based on the account name. In addition, for accounts these lend funds, according to the duration of loan record the payments, the enterprises would divided it into long-term borrowing and short-term borrowing. Institution was on the contrary, institution loan would like to put the money into the unit interior projects, these two approaches was different, the two units in the overall financial management had a certain difference, also brought the certain effect accounting of financial records management work, the formation of the differences and the nature of the unit had a certain relationship between.

Progress in Machines and Systems Volume 8 Number 2 October 2019 


\subsection{The Difference on the Tax Payment}

For taxes payment, a unit must fulfill the responsibility, at the same time, it was also a important aspect for constituent units for financial problems. Both institutions and enterprises needed to pay taxes to the state. While, these two units had a certain differences on the tax issues in processing. The two units would purchase a certain amount of production data, for example, under the normal circumstances, the institution tax payment method was more complicated, they would launch a distinction and made to taxpayers. In dealing with these tax, generally, there were two ways, the first was the institution purchase was the price without tax; The second was the material production of institution for its own use which was include tax. Instead, enterprises in the treatment of the tax issue was relatively simple, they divided taxpayers into two kinds: general taxpayer and small unit taxpayer. For the general taxpayer, there was no need for them to pay tax for the raw material, for the post one, when dealing with matter, it became relatively easy. It mainly due to dividing the taxpayers into tow type: the general taxpayer, and small-scale taxpayers. There was no tax when the former purposed raw material, the latter in purchasing production material always had certain tax price.

\subsection{Difference in Expenditure Accounting}

In daily business activities, any enterprises needed process the expenditure. In the treatment of the cost of the accounting. Firstly, the enterprise unit main purpose was profit, so what they thought more was cost and profit accounting, based on this, they implemented a series of measures to manage the production of the enterprise profit, their ultimate goal was the cost accounting and accounting profits. Instead, Institutions were different, when check the cost accounting, the profits was not considered. In daily operation process, when needed to check the cost accounting, they could count it into the unit itself spending account. Through the comparison and analysis, institutions and enterprises had a certain difference on cost calculation, the cause of the difference was the purpose of the unit content of cash flow.

\subsection{Differences in Accounting and Business Activities}

No matter institutions or enterprises, in the process of production and business operation, they would have a business activity, on the accounting performance of both thing was not the same. Due to the business unit's business activities mainly for business class and professional class, its spending and income included the business activities of the whole business activities of the expenditure and revenue. These accounts were in the business activities between accounting difference. Took pending as the research object, this study set the activities in the relevant administrative department office expenses, there was a difference between, enterprises would take the activity cost accounting in the records of financial management, and professional activities associated with the business entity would be as spending.

\subsection{The Difference in Financial Statements}

Institutions and enterprises also had certain difference on accounting statements, institution accounting statements, such as the daily revenue expenditure tables, sheets, government subsidies, etc. This unit report mainly reflected business entity for a specified period of operating conditions and relevant information, these statements played a certain reference value, and was reference to the relevant units and daily inspection unit. And could be the instruction of operation be accordance with the specification. While the enterprise unit was not like this, their report was mainly for some enterprise profit statement, balance sheet and cash flow table, etc. These statements could react systematically and comprehensive enterprise information in the normal course of business activities, and also could reflect enterprises in financial management and operation for the enterprise decision makers to provide some beneficial information, convenient they work out scientific and reasonable scheme.

\subsection{Difference on Assets Procurement Processing}

Production materials could be required for enterprises and institutions in the daily procurement internal needs. The accounting staff shall make records of these information. Institutions and enterprises had a certain differences between, the purchased assets of enterprises had a category of "fixed assets", recycling had a "bank deposit" category. While, institutions unit was different, accounting staff would had two records, one was the category" fixed assets" and "non-current assets funds"; another was the "services" and "operating expenditure".

\subsection{Difference on Accounting of Final Transferring}

There were many differences for the final transferring of institutions and enterprises. For institution, their final accounting transaction, the incomes and expenditure accounts were shifted to company annual profits accounts. The purpose was to convenient the proportional distribution of the profits. While, the institution was different, accounting staff transferred incomes accounts to finance allowance accounts, according to the different properties and USES funds, and expenditure accounts were 
shifted into non fiscal allowance accounts. The funds were transferred into fiscal spending allowance accounts in the end of annual year.

\subsection{Differences in Reporting}

There were certain difference of enterprises and institutions in preparation of accounting statements. Under the normal circumstances, there were main four reasons for institutions: the profit statement, balance sheet, funds recycling statement and shareholders' equity table. These statements, report, or table could fully reflect the whole enterprise daily financial situation, operating conditions and capital structure, and it was very beneficial to facilitate the enterprise to provide information to the enterprise users. The purpose was to help them make decisions more scientific and effective. For institution reports, there were main three types: the balance sheet, income and expenditure tables and fiscal subsidy. For institutions, these tables were mainly embodies the business entity in a specific period of time's financial situation and business activities. These tables could provide favourable information for institutions in economic and financial management, and could also help the business unit leadership analysis unit interior operation specification and improve the efficiency of financial management.

\subsection{The Difference on Goods Inventory Processing}

Institutions and enterprises had certain difference on goods inventory. General storage could be less at some tine, and full at some time. This condition was consistent with the loss and gain of profits. The checking of goods inventory of enterprises was according to the batches of examination and approval in a time order, and could be divided into pending property loss accounts and different credit management cost respectively. While, the profit and loss of enterprise was in the same situation, which could be divided into property accounts loss and different situation to be processed respectively and saving management charges. While, institutions was on the contrary, the goods storage and inventory was not according to the examination and approval, and would not based on the record of the income, the profit and loss of these goods was directly recording of expense.

\section{Conclusion}

As is known to all, enterprises and public institutions were the two main forms of our country unit, this two units had significant difference at unit properties and funds operation conditions. These may lead to both had many differences in accounting and financial management. Through the series of analysis of studies, this paper had confirmed the differences of financial management, accounting records, business activities, the accounting and reporting. The purpose was to give the accounting management personnel assist to these unit in order to improve their efficiency in the following work.

\section{References}

[1] Yun ZHANG. (2012). Difference analysis of institutions and enterprises accounting financial processing, Accounting and Finance, 2012, 8. 56.

[2] Pei-shu WEI. (2013). Similarities and differences of institutions and enterprises in the accounting treatment, Modern Economic Information, 2013, 8. 115.

[3] Ai-mei XU. (2014). Comparison of institutions and enterprises accounting financial processing, Finance Managing, 2014, 2. 55-58.

[4] An-xiang TANG. (2006). Influence of the limitations of financial accounting in the new period to accounting information quality, Commercial Economy, 2009 (20).

[5] Lan-lan XIE. (2008). Treatment of human resource accounting from reliability and relevance, Caikuai Yuekan (integrated). 2008(06).

[6] Li-yan WANG, Li-na WU, Zheng-ying LUO. (2012). Accounting principle. Beijing: Peking University Press, 2012 (06). 